Vitaliia Koibichuk,

Ph.D., Associate Professor, Sumy State University, Ukraine

ORCID ID, 0000-0002-3540-7922

e-mail:v.koibichuk@uabs.sumdu.edu.ua

Natalia Ostrovska,

Dr.Sc., Associate Professor, Yuriy Fedkovych Chernivtsi National University, Ukraine

ORCID ID, 0000-0002-7259-7403

e-mail: n.ostrovska@chnu.edu.ua

Flora Kashiyeva,

Ph.D., Associate Professor, Azerbaijan State University of Economics, Azerbaijan

ORCID ID, 0000-0002-4858-897X

e-mail: flora_kashiyeva@unec.edu.az

Aleksy Kwilinski,

Dr.Sc., Professor, The London Academy of Science and Business, England

Sumy State University, Ukraine

D ORCID ID, 0000-0001-6318-4001

e-mail: a.kwilinski@london-asb.co.uk

Correspondence author: v.koibichuk@uabs.sumdu.edu.ua

\title{
INNOVATION TECHNOLOGY AND CYBER FRAUDS RISKS OF NEOBANKS: GRAVITY MODEL ANALYSIS
}

Abstract. In the system of global information space, it is important to adequately calculate and assess the factors of successful functioning of the banking system, which are directly the engines of the country's development, economic stability, especially from the standpoint of qualitative measurement of innovative technology and human capital in rapid cyber fraud. The work is devoted to studying factors that describe the components of efficiency and potential use of innovative technologies in neo-banking in 90 countries to determine the level of risk of their use for money laundering based on gravitational modeling methodology. The authors substantiated that using four factors consisting of 13 components of digital evolution is expedient. Three indicators (access infrastructure, transaction infrastructure, and fulfillment infrastructure) allowed forming the supply condition factor. It provides a score on developing digital and physical infrastructure to ensure the digital economic system's quality. The «demand conditions» factor consists of 4 indicators (human quality level, device absorption level and digital broadband level, digital payment absorption), which show how much consumers are willing and able to participate in the digital economic system and whether they have the tools and skills needed to connect to the digital economy. Three indicators (institutional effectiveness and trust, institutions and the business environment, institutions and the digital ecosystem) shaped the «institutional environment» factor. It relates to research on countries' support for digital legislation, governments' investment in digitalization, and regulations. Regulate the quality of storage and access to digital data. The fourth factor of «innovation and change» consists of three features that characterize the state of key innovative economic system inputs (talents and capital), processes (i.e., cooperation between universities and industry), and outputs (i.e., new scalable digital products and services). The generalized indicator was formed based on these indicators. It characterizes the degree of risk of using the services of neobanks of the studied countries by economic agents or individuals to legalize criminal proceeds. At the first stage of the proposed method, the authors substantiated the statistical significance and possibility of using the studied indicators. The procedure of logarithmic normalization was carried out. The toolkit of descriptive statistics of the Statgaphics Centurion package provided the normalization parameters. In the second stage, the indicators were collapsed using a geometric weighted average, which provides meaningful information about the average dynamics rate. The third stage provided calculating the value of the

Cite as: Koibichuk, V., Ostrovska, N., Kashiyeva, F., \& Kwilinski, A. (2021). Innovation Technology and Cyber Frauds Risks of Neobanks: Gravity Model Analysis. Marketing and Management of Innovations, 1, 253265. http://doi.org/10.21272/mmi.2021.1-19 
V., Koibichuk, N., Ostrovska, F., Kashiyeva, A., Kwilinski. Innovation Technology and Cyber Frauds Risks of Neobanks: Gravity Model Analysis

integrated rating assessment of the degree of risk of using innovative technologies, services, and neobanking services for money laundering based on gravity modeling methods. The findings showed that $12.22 \%$ of the studied countries had a high degree of risk, $25.56 \%$ - a medium level of risk, $25.56 \%$ - a risk below the average level, for $36.66 \%$ of countries - the risk was almost absent.

Keywords: neobanks, innovation financial technologies, cyber frauds risks, digital evolution components, gravity model analysis.

Introduction. The term neobank (virtual, digital, Internet banking) has been actively used since 2017. Neobanks are fintech companies that offer both standard banking services entirely online and nontraditional ones (peer-to-peer payments, financial advisory robots, cryptocurrency transactions, and crowdfunding platforms to raise funds for certain financial projects or their intangible equivalents that are directly related to the project). The innovative use of fintech neobanks challenges traditional banks' existence, on the one hand, and increases the risk of money laundering and the use of various fraud schemes. As of the end of December 2020, the number of neobanks in the world was 256, and many banks are still being prepared for launch (Stagmeier and Friedental, 2020). Simultaneously, neobanks could operate without a full banking license, have a license for individual financial services, and conduct all other activities through a partnership with ordinary banks (Naser, 2019). For example, in Europe, the Electronic Money Institution (EMI) neobank, under such a license, could issue cards, transfer funds, and issue digital money (Electronic Money Institution, 2021). Another example of the organization of neobank activity is the model of cooperation with another bank. In this model, all regulatory compliance obligations, together with credit risks, apply to partner banks, and the neobank provides only technological solutions. Most neo-banks in the world work according to this scheme of the organization of their activities. It only complicates financial monitoring procedures by the state and relevant monitoring services, law enforcement agencies for legalizing criminal proceeds. First, the complexity of quality monitoring is explained by the number of companies-investors of the studied neobank, their physical location, and their compliance with all legal norms and relevant licensing requirements (Savchenko et al., 2020). Second, the peculiarities of using innovative financial and economical automated technologies, the level of organization of a secure connection of stakeholders in financial transactions (Lopez et al., 2019). Both examples of neobanks organization have a high degree of risk associated with the intervention of fraudsters, impostors, obtaining and misappropriating identification and authentication information on the data of economic agents and individuals (clients) for criminal money laundering (Levchenko et al., 2019). Also, there may be a risk appetite or risk appetite of the financial institution or bank itself. Cooperation is organized with the neobank, which allows fraud to internal employees or companies-investors. According to the report of leading global professional services company Accenture (Accenture's Digital Banking Tracker, 2020), fintech apps showed the highest rate of growth in terms of download numbers compared to other financial products, such as traditional banking apps, budgeting assistants, or payment utilities. Also, the trend of increasing neobank users is associated with high-interest rates on deposits, as they work without branches, have fewer employees, and this explains the higher interest rates on deposits: simplified method of obtaining loans, as modern automated technologies for verifying customer information are used; low service tariffs and large modern tools offered for financial analytics.

One cannot fail to note the global pandemic's impact on economic agents' behavior and changes in business processes around the world (Nur-Al-Ahad and Nusrat, 2019). Traditional banks have to compete with each other and fintech companies, which are rapidly increasing their market share, as they are not burdened with capital costs and a large staff. On the one hand, the development of digital banking challenges traditional banks. On the other, it is a lure for criminals. They could use many fraudulent schemes and misappropriate funds of individuals, economic agents and use neobank as an intermediate link in money laundering. 
V., Koibichuk, N., Ostrovska, F., Kashiyeva, A., Kwilinski. Innovation Technology and Cyber Frauds Risks of Neobanks: Gravity Model Analysis

Therefore, for a thorough study of risk assessment of the use of neobank to legalize criminal proceeds, it is proposed to use the influence of factors that comprehensively describe digital evolution components in terms of supply conditions, demand conditions, institutional effectiveness and trust, innovation, and change.

Literature Review. The sphere of neobanking is relatively young and is just beginning to develop. Accenture's Digital Banking Tracker found that neobanks have nearly tripled their customer base in the last years, from 7.7 million customers in 2018 to almost 20 million in 2019. This current growth rate of $150 \%$ outpaces the $2 \%$ growth for traditional challenger banks and $1 \%$ for incumbents. However, many publications are devoted to the issue of research on money laundering using digital banks. Thus, for the query «Money laundering in digital bank» in the Scopus database, were found 27 studies for the period from 2017 to 2020, conducted by scientists from 47 universities around the world (Fig. 1).

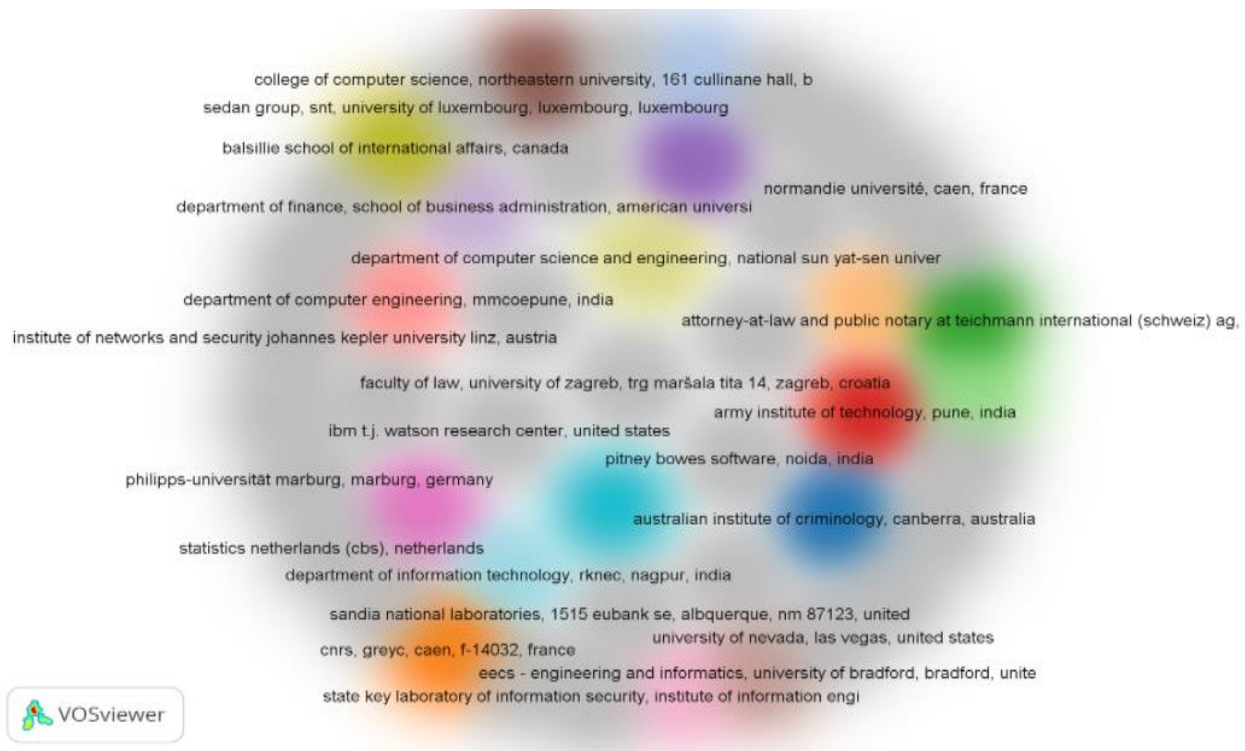

Figure 1. Bibliometric analysis of scientific publications on the subject of research on the use of innovative technologies of neobanks for money laundering

Sources: developed by the authors using VOSviewer 1.6.15 software tools.

Following CB Insights report (Private Market Data CB Insights, 2020), a vast army of neobanks targets all sorts of consumer and small-business niches - from Millennial investors to dentists and franchise owners. There are 5,000 startups worldwide offering new and traditional financial services, up from 2,000 just three years ago. In the first nine months of 2019 , venture capitalists poured $\$ 2.9$ billion into neobanks, compared with $\$ 2.3$ billion in all of 2018. Maksimova et al. (2020) proposed determining the risk typology for peer-to-peer lending in a financial architecture transformed by digitalization and the epidemiological situation. The study highlights key features that allow investigating the risk of peer-to-peer lending and determine fraudulent schemes' scenario behavior. Key traffic channels for neobanks are direct use of mobile applications on IOS, Android platforms and own websites, call centers - 52.29\%; e-mail - 1.45\%; referrals $-4.43 \%$ (a member of the affiliate program, who registered on the recommendation of another participant, such a marketing scheme is widespread on the Internet and provides registration on sites that offer relevant services); social $-2.9 \%$; organic search $-32.34 \%$; paid search $-5.7 \%$; display ads $-0.88 \%$ (Accenture's Digital Banking Tracker, 2020). For example, 98\% of China's consumer population consider 
mobile payments to be the most commonly used payment method in 2020. It is 5\% more than in 2019 . $85 \%$ made a payment by scanning a QR code, which is $6 \%$ higher than in the same period in 2019 . As for the state of the Ukrainian banking sector, according to a study within the USAID Project «Financial Sector Transformation» (Ukrainian Financial Sector Transformation, 2019), Ukrainian banks are accepting digital transformation not as an opportunity but as like a «parallel world». And as a result, Ukrainian banks currently have a low level of participation in fintech companies' capital, members of the bank's board have limited experience in the fintech industry (Levchenko et al., 2018; Vasylieva et al., 2017). Moreover, only $50 \%$ of banks have a digital strategy. According to the Ministry of Finance of Ukraine, currently, mobile applications are presented only in 39 banks out of 75 . Simultaneously, all neobanks work through cooperation with existing banks. It would be complicated for neobanks to comply with all the requirements for real banks' traditional reporting forms. The most active and popular among economic agents and individuals are two virtual banks. The first one is Monobank (using a banking license No 92 from 10 October 2011), JSC «Universal Bank» with «Specialized Savings Bank» status since November 2018, as more than $50 \%$ of the bank's assets are deposits of individuals. Since July 2019 , it is a systemically important bank defined by the NBU (Buriak et al., 2015). The second bank mentioned above is SportBank (used by the NBU license No 84 from 25.10.2011 JSC «TASKOMBANK» and NBU license No 247 dated 15.11.2011 of JSC «OXY BANK»). These banks provide their services without the traditional branch infrastructure, using Internet platforms and mobile applications. Today, there are many different problematic aspects of quality assessment of the risk of economic agents and individuals using neobanking opportunities to legalize criminal proceeds.

Methodology and research methods. The study is based on factors that describe the efficiency and evolution of financial technologies in four complex features. The supply conditions factor consists of indicators of access infrastructure, transaction infrastructure, and fulfillment infrastructure. These indicators characterize how developed the infrastructure is, both digital and physical, necessary for the digital economic system's organization (capacity level, quality of technical components required for ecommerce). The second factor used in the study is the demand conditions factor. Here it is proposed to use indicators of the human condition, device and broadband uptake, digital inclusion, and digital payment uptake. This factor allows determining how willing and able consumers are to participate in the digital ecosystem (Zolkover and Terziev, 2020; Vasylieva et al., 2018b; Kyrylov et al., 2020; Lyulyov et al., 2020; 2021; Miskiewicz 2020b; 2021; Pajak et al., 2017), and whether they have the tools and skills needed to connect to the digital economy (Bilan et al., 2019b; Bogachov et al., 2020; Dzwigol, 2020; Dzwigol \& Dzwigol-Barosz, 2018; Dzwigol et al., 2020; Kuzior et al., 2019; Kwilinski \& Kuzior, 2020; Kwilinski et al., 2020; Melnychenko, 2019; 2020; 2021; Miskiewicz 2019; 2020a). The third factor of the institutional environment consists of institutional efficiency and trust indicators, institutions and the business environment, institutions, and the digital ecosystem. It is essential to study the impact of this factor on neobanking, as it provides an opportunity to investigate: whether countries support the current legislation, the government in terms of digitalization of all areas of activity, or hinder the development of digital technologies; whether governments are investing in digitalization; whether regulations allow the use and storage of digital data to increase them, or, conversely, create barriers (Milon et al., 2018; Aleksander et al., 2020). The fourth factor of innovation and change concerns the state of key innovation ecosystem inputs (e.g., talent and capital, Zwerenz, 2020), processes (cooperation between universities and industry), and outputs (i.e., new scalable digital products and services).

This study involved the indicators from 90 countries, using 45 different databases (Digital Evolution Index, 2019), as well as an analytical report by Chakravorti et al. (2020) and Access Private Market Data Database SB Insights (2020). Thus, 14 indicators were used to assess the risk level of using neobanks as potential objects for money laundering: K1 - access infrastructure; K2 - transaction infrastructure, K3 fulfillment infrastructure; $\mathrm{K} 4$ - state of the human condition; K5 - device and broadband uptake; K6 - 
V., Koibichuk, N., Ostrovska, F., Kashiyeva, A., Kwilinski. Innovation Technology and Cyber Frauds Risks of Neobanks: Gravity Model Analysis

digital inclusion, K7 - digital payment uptake; K8 - institutional effectiveness and trust; K9 - institutions and the business environment; K10 - institutions and the digital ecosystem; K11 - inputs; K12 processes, $\mathrm{K} 13$ - outputs, $\mathrm{K} 14$ - total funds of neobanks $(\$, \mathrm{M})$. The values of $\mathrm{K} 1-\mathrm{K} 13$ indicators are given in points measured on a scale from 0 to 100. The larger the indicator value, the better this indicator characterizes its content load. In describing these indicators' impact on forming the risk of using neobanking for money laundering, formal and logical conclusions, these indicators are indicatorsstimulants. For example, the indicator K7 (digital payment uptake) characterizes the absorption of digital payments. Accordingly, the greater its value, the more such transactions are made, the more opportunities a country has for the use of neobanking, given the available fintech innovations and human potential. Table 1 shows the numerical data fragment of this study.

Table 1. Initial statistical characteristics of the innovation technology risk and cyber frauds of neobanks

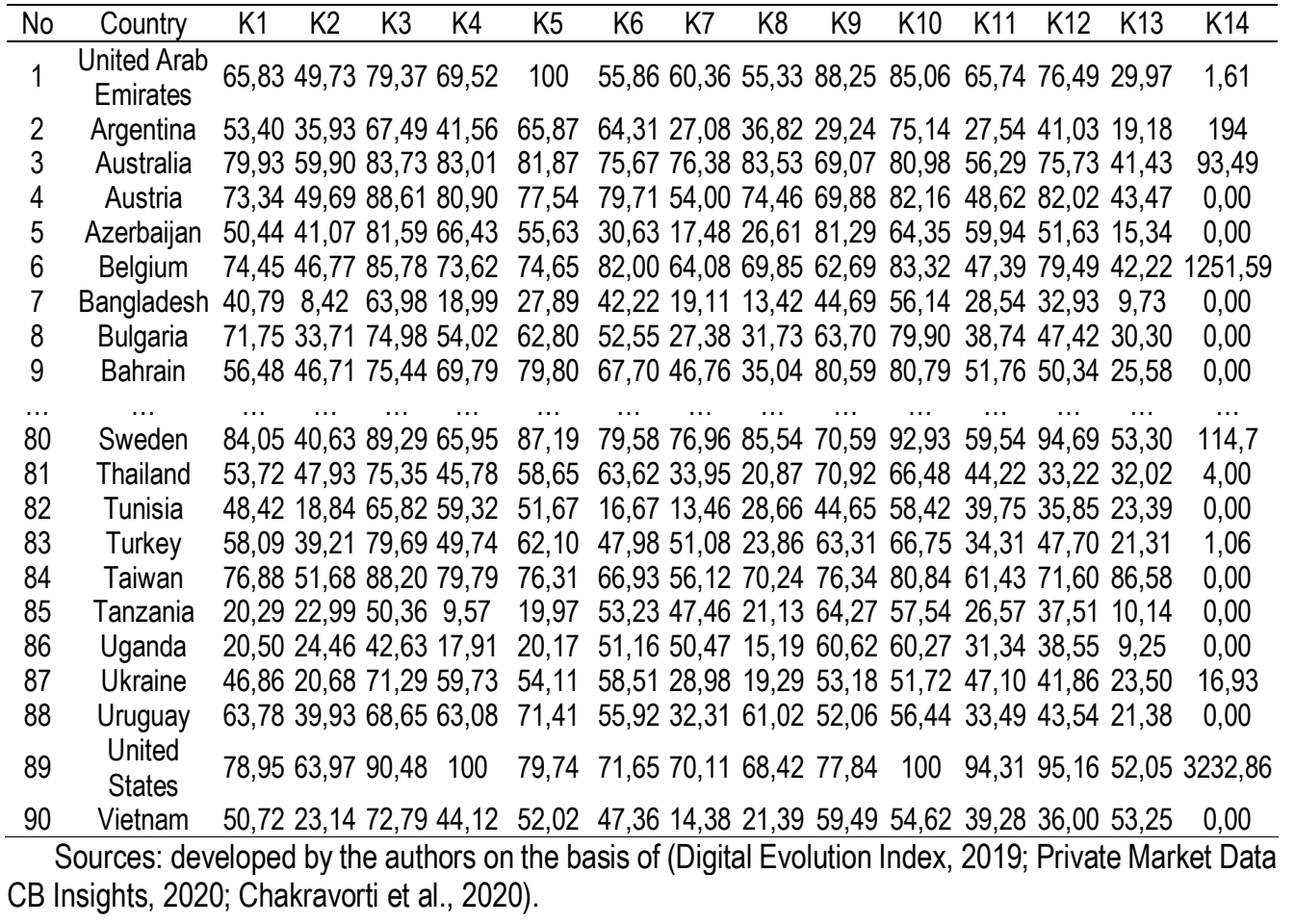

The assessment of the level of risk of money laundering with the use of neobanks' financial technologies is based on the methodology of gravitational modeling (Ferwerda et al., 2011). Its essence is to use the law of gravitational force and gravitational gravity in social phenomena:

$$
V_{i j}=\frac{p_{i} p_{j}}{d_{i j}^{2}} k
$$

where $\mathrm{V}_{\mathrm{ij}}$ - assessment of the interaction between two objects $\mathrm{i}$ and $\mathrm{j}$; the value of the integrated index; $\mathrm{k}$ - the coefficient of conformity; $p$ - estimated importance of the object (weight); $d 2_{i j}$ - the distance between objects. 
The risk of legalization of countries' criminal income when using neobanking services by any economic agents or individuals is interpreted as follows. An individual country attracts risky transactions with force directly proportional to the rating of the risk of legalization of the country and regulatory country that is laundered criminal funds and inversely proportional to the square of the value of distance. Distance is a quantitative assessment of the difference between the country under study and the regulations in the process of risk operations (2):

$$
L_{j}=\frac{I_{i} I_{j}}{d_{i j}^{2}}
$$

where $L_{j}$ - assessment of the strength of interaction between economic agents using neobanking, the country under study and the $j$-th country in terms of legalization of criminal proceeds; $I_{i}$ and $l_{j}$ - integrated rating assessments of the level of risk of use of financial institutions of the studied country and the j-th country for legalization of criminal proceeds; $d_{2} 2_{i j}$ - the distance between countries, which characterizes the estimated difference between the study country and the j-th country (Juarez-Garcia, 2020). The distance $\mathrm{d}^{2}{ }_{\mathrm{ij}}$ between the studied country and the j-th country is determined based on the values of K14 total funds of neobanks.

The procedure for calculating integrated rating indicators of the level of risk of using neobanking services by economic agents or individuals is carried out within two stages. At the first stage, it is necessary to bring the research indicators $(\mathrm{K} 1-\mathrm{K} 13)$ to a single scale of measurement from 0 to 1, i.e., carrying out their normalization. There is a large variety of methods that allow standardization. Still, for further qualitative convolution of the studied indicators, it is necessary to carry out such a transformation considering the distribution laws and development patterns' numerical characteristics. Therefore, it is proposed to carry out the normalization procedure using a modified logistic transformation function, taking into account its apparent advantages (3):

$$
y_{i j}=\frac{1}{1+e^{-3 \frac{x_{i j}-p_{i}}{q_{i}-p_{i}}}},
$$

where $y_{i j}$ - the normalized value of the i-country of $j$-index, $q_{i}-$ the value of the indicator $x_{i j}$, at which the conversion function takes a value not less than 0,$95 ; p_{i}$ the value of the indicator $x_{i j}$, at which the conversion function becomes 0,5 (Us et al., 2018). It should be noted here that the level of the criterion's converted values depends on the establishment of $q_{i}$ and $p_{i}$.

In terms of the countries studied, not all countries directly use neobanking. However, they use online services in terms of traditional banking or do not use them at all. Thus, for the country, the value of K14 is 0 . For other countries, total funds of neobanks are given in $\$$ million ( describes the distance between the studied countries, formula (2)). Therefore, for qualitative normalization of the distance indicator, it is advisable to use formula (4).

$$
\widetilde{m_{l \jmath}}=\left(1+e^{\frac{\overline{m_{l}}-m_{i j}}{\sigma_{j}}}\right)^{-1}
$$

where $\widetilde{m_{l}}-$ normalized value of the i-country of $\mathrm{j}$-index; $\overline{m_{l}}$ - the average value of j-indicator; $m_{i j}$ the value of i-country of j-index; $\sigma_{j}$ - standard deviation of the j-indicator. 
In the second stage, the input indicators are convoluted using the geometric weighted average. It is this convolution procedure that allows calculating the average rate of dynamics (Bilan et al., 2019a):

$$
I_{p}=\sum \sqrt[n_{i}]{\prod_{i=1}^{13} K_{i}^{n_{i}}}
$$

where $I_{p}$ - integrated rating evaluations of the financial institution risk in the studied country for money laundering; $K_{i}$ - the studied indicator $i=\overline{1,13} ; n_{i}$ - frequency of the grouping feature.

At the third stage, the studied countries' overall integrated rating neobanking to legalize criminal proceeds is calculated based on formula 6 . It shows the normalized values of indicators on a scale from 0 to 1 . The value close to one shows the highest level of risk, and a value close to zero has the lowest level of money laundering risk of financial institutions or economic agents (Lyeonov et al., 2020):

$$
\widetilde{L_{J}}=\frac{L_{j}}{\min _{j} L+\sigma\left(L_{j}\right)}
$$

where $\widetilde{L_{J}}$ - assessment of the risk to involve the studied country by j-state in the money laundering scheme $[0 ; 1] ; L_{j}$ - assessment of the risk to involve the studied country by the j-country into money laundering; $L$ - maximum value of the risk to involve the observed country by j-state in money laundering; $\sigma\left(L_{j}\right)$ - standard deviation to assess the risk in the surveyed country by the j-th country in the money laundering.

Results. Using the proposed methodology, the procedure of normalization of indicators $\mathrm{K} 1-\mathrm{K} 13$, describing the impact of 4 factors in terms of risk of using economic agents of financial institutions or individuals of neobanking technologies for money laundering in terms of components supply conditions, demand conditions, institutional environment, and innovation and change based on a formula (3). The logarithmic normalization procedure's characteristics are determined based on the respective indicators' statistical factors and their distribution laws (Table 2).

Table 2. Numerical characteristics of digital evolution components K1 - K13 for studied countries

\begin{tabular}{ccccccccccccccc}
\hline $\begin{array}{c}\text { Numerical } \\
\text { characteristic }\end{array}$ & $\mathrm{K} 1$ & $\mathrm{~K} 2$ & $\mathrm{~K} 3$ & $\mathrm{~K} 4$ & $\mathrm{~K} 5$ & $\mathrm{~K} 6$ & $\mathrm{~K} 7$ & $\mathrm{~K} 8$ & $\mathrm{~K} 9$ & $\mathrm{~K} 10$ & $\mathrm{~K} 11$ & $\mathrm{~K} 12$ & $\mathrm{~K} 13$ \\
\hline Count & 90 & 90 & 90 & 90 & 90 & 90 & 90 & 90 & 90 & 90 & 90 & 90 & 90 \\
Average & 58,83 & 38,80 & 72,60 & 53,00 & 61,20 & 59,54 & 42,62 & 43,86 & 63,08 & 69,59 & 44,96 & 55,10 & 32,87 \\
Median & 58,27 & 39,29 & 75,39 & 58,12 & 65,57 & 61,78 & 42,69 & 37,44 & 62,94 & 74,16 & 42,60 & 50,31 & 27,71 \\
$\begin{array}{l}\text { Variance } \\
\text { Standard }\end{array}$ & 338,67 & 196,28 & 287,92 & 520,12 & 381,45 & 334,02 & 467,70 & $623,99229,61$ & 259,77 & $193,31371,01432,57$ \\
$\begin{array}{c}\text { deviation } \\
\text { Coefficien of }\end{array}$ & 18,40 & 14,01 & 16,97 & 22,81 & 19,53 & 18,28 & 21,63 & 24,98 & 15,15 & 16,12 & 13,90 & 19,26 & 20,80 \\
$\begin{array}{c}\text { variation } \\
\text { Standard error }\end{array}$ & 0,31 & 0,36 & 0,23 & 0,43 & 0,32 & 0,31 & 0,51 & 0,57 & 0,24 & 0,23 & 0,31 & 0,35 & 0,63 \\
$\quad$ Minimum & 20,29 & 6,66 & 11,70 & 0,00 & 17,23 & 3,52 & 10,04 & 5,48 & 15,54 & 21,05 & 23,47 & 27,03 & 6,76 \\
$\begin{array}{c}\text { Maximum } \\
\text { Range }\end{array}$ & 100,00 & 100,00 & 96,70 & 100,00 & 100,00 & 94,96 & 100,00 & 95,43 & 98,47 & 100,00 & 94,31 & 95,38 & 97,89 \\
$\begin{array}{c}\text { Standard } \\
\text { skewness }\end{array}$ & 0,04 & 93,34 & 85,00 & 100,00 & 82,77 & 91,44 & 89,96 & 89,95 & 82,93 & 78,95 & 70,84 & 68,30 & 91,13 \\
$\begin{array}{c}\text { Standard } \\
\text { kurtosis }\end{array}$ & $-1,09$ & 6,64 & $-4,82$ & $-1,39$ & $-1,93$ & $-3,10$ & 1,45 & 1,63 & $-1,81$ & $-3,33$ & 3,58 & 2,18 & 5,04 \\
\hline
\end{tabular}

Sources: developed by the authors. 
V., Koibichuk, N., Ostrovska, F., Kashiyeva, A., Kwilinski. Innovation Technology and Cyber Frauds Risks of Neobanks: Gravity Model Analysis

To determine the characteristics of normalization and $p_{i}$ qualitatively and, firstly, it is necessary to start from the relevant indicator's content, namely, whether it is a stimulus for assessing the risk of neobank in fraudulent schemes or a disincentive. Then, the coefficient variations should be considered. For the statistical significance of the indicator, it should exceed $5 \%$. Finally, it is necessary to use especially careful indicators in which the values of the coefficients Standard skewness and Standard kurtosis go beyond the interval $(-2 ; 2)$. That is because these statistics' values outside the range of -2 to +2 indicate significant departures from normality, which would tend to invalidate any statistical test regarding the standard deviation. Table 3 presents the normalization parameters' values by the formula (3).

Table 3. The values of parameters $q_{i}$ and $p_{i}$ for standardization of initial indicators

\begin{tabular}{cccccccccccccc}
\hline \multirow{2}{*}{ Parameter } & K1 & K2 & K3 & K4 & K5 & K6 & K7 & K8 & K9 & K10 & K11 & K12 & K13 \\
\hline$q$ & 100 & 100 & 96,70 & 100 & 100 & 94,96 & 100 & 95,43 & 98,47 & 100 & 94,31 & 95,38 & 97,89 \\
$p$ & 58,27 & 39,29 & 75,39 & 58,12 & 65,57 & 61,78 & 42,69 & 37,44 & 62,94 & 74,16 & 42,60 & 50,31 & 27,71 \\
\hline
\end{tabular}

Sources: developed by the authors.

Transformed values comparable with each other are presented on a scale from 0 to 1 . They could be used in further mathematical calculations.

Table 4 shows the fragment of normalized values of $\mathrm{K} 1-\mathrm{K} 14$ for nonlinear transformation functions (3) and (4).

Table 4. Standardized values of the indicators for the assessment of neobanks cyber frauds risks

\begin{tabular}{|c|c|c|c|c|c|c|c|c|c|c|c|c|c|c|c|}
\hline No & Country & K1 & $\mathrm{K} 2$ & K3 & K4 & K5 & K6 & K7 & K8 & K9 & K10 & K11 & K12 & K13 & K14 \\
\hline 1 & $\begin{array}{c}\text { United Arab } \\
\text { Emirates }\end{array}$ & 0,633 & 0,62 & 0,637 & 0,693 & 0,953 & 0,369 & 0,7 & 0,71 & 0,894 & 0,78 & 0,793 & 0,8 & ,524 & 0,439 \\
\hline 2 & Argentina & 0,413 & 0,459 & 0,248 & 0,234 & 0,507 & 0,557 & 0,306 & 0,492 & 0,055 & 0,528 & 0,29 & 0,35 & 0,410 & 0,527 \\
\hline 3 & Australia & 0,826 & 0,735 & 0,764 & 0,856 & 0,805 & 0,778 & 0,8 & 0,916 & 0,626 & 0,688 & $0,68 \mathrm{~s}$ & 0,84 & 0,643 & 0,481 \\
\hline 4 & Austria & 0,747 & 0,626 & 0,865 & 0,836 & 0,739 & 0,835 & 0,6 & 0,872 & 0,642 & 0,717 & 0,586 & 0,892 & 0,662 & 0,438 \\
\hline 5 & Azerbaijan & 0,363 & 0,522 & 0,706 & 0,645 & 0,296 & 0,056 & & 0,363 & 0,825 & 0,242 & 0,732 & 0,522 & 0,371 & 0,438 \\
\hline 6 & Belgium & 0,762 & 0 , & 0,812 & 0,752 & 0,688 & 0,862 & 0 & 0,842 & 0,495 & 0,143 & 0,569 & 0,875 & 0,650 & 0,886 \\
\hline 7 & Bangladesh & 0,222 & 0 , & 0,167 & 0,057 & 0,036 & 0,146 & 0,226 & 0,224 & 0 , & 10 & 307 & . & 0,317 & 0,438 \\
\hline 8 & Bulgaria & 0,725 & 2 & 0 , & 0,427 & 0,440 & 0,303 & & 27 & 0 & 601 & 444 & 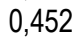 & 528 & 0,438 \\
\hline 9 & Bahrain & 0,468 & & 0,502 & 0,698 & 0,776 & 0,631 & 0 , & 0,469 & 0,816 & 00 & , ,630 & 0,500 & 0,477 & 0,438 \\
\hline ח९ & $\cdots$ & & & & & & & & & & & & & & \\
\hline 80 & Sweden & 0,865 & 5 & 0,876 & 0,637 & 0,868 & 0,833 & 0,85 & 0,923 & 0,656 & 0,89 & 0,728 & ys & 749 & 0,490 \\
\hline 81 & Thailand & 0,419 & 0,605 & 0,499 & 0,292 & 0,354 & 0,542 & 0 & 0,298 & 0,662 & 0 , & 0,524 & 0,243 & 546 & 0,440 \\
\hline 82 & Tunisia & 0,330 & 0,267 & 0,206 & 0,521 & 0,230 & 0,017 & 0,1 & 0,388 & 0,176 & 0,139 & 0,459 & 76 & 0,454 & 0,438 \\
\hline 83 & Turkey & 0,497 & 0,499 & 0,647 & 0,354 & 0,425 & 0,223 & 0,608 & 31 & 0,508 & 0,29 & 0,382 & 0,457 & 0,432 & 0,439 \\
\hline 84 & Taiwan & 0,792 & 0,648 & 0,859 & 0,825 & 0,718 & 0,614 & 0,669 & 0,845 & 0,756 & 0,685 & 0,749 & 0,805 & 0,925 & 0,438 \\
\hline 85 & Tanzania & 0,061 & 0,309 & 0,029 & 0,030 & 0,018 & 0,316 & 0,562 & 0,301 & 0,528 & 0,127 & 0,283 & 0,299 & 0,321 & 0,438 \\
\hline 86 & Uganda & 0,062 & 0,325 & 0,010 & 0,053 & 0,019 & 0,277 & 0,601 & 0,240 & 0,451 & 0,166 & 0,342 & 0,314 & 0,312 & 0,438 \\
\hline 87 & Ukraine & 0,306 & 0,285 & 0,360 & 0,529 & 0,269 & 0,427 & 0,328 & 0,281 & 0,305 & 0,069 & 0,565 & 0,363 & 0,455 & 0,446 \\
\hline 88 & Uruguay & 0,598 & 0,508 & 0,279 & 0,588 & 0,625 & 0,371 & 0,367 & 0,772 & 0,28 & 0,113 & 0,37 & 0,389 & 0,433 & 0,438 \\
\hline 89 & $\begin{array}{l}\text { United } \\
\text { States }\end{array}$ & 0,81 & 77 &, 89 & 0,953 & 0,775 & 0,709 & 0,808 & 0,832 & 0,779 & 0,95 & 0,953 & 0,952 & 0,739 & 0,997 \\
\hline 90 & Vietnam & 0,368 & 0,310 & 0,410 & 0,268 & 0,235 & 0,213 & 0,185 & 0,304 & 0,428 & 0,094 & 0,452 & 0,278 & 0,749 & 0,438 \\
\hline
\end{tabular}

Table 5 shows the convolution of the input indicators using the geometric weighted average (5) and the calculation of the integrated indicator based on the gravity model (6) for all countries of the study. 
V., Koibichuk, N., Ostrovska, F., Kashiyeva, A., Kwilinski. Innovation Technology and Cyber Frauds Risks of Neobanks: Gravity Model Analysis

Table 5. Integrated rating index $\left(I_{p}\right)$ of the money laundering risk of economic agents, and neobanks cyber frauds risks assessment based on the gravity model $\widetilde{L}$

\begin{tabular}{|c|c|c|c|c|c|}
\hline Country & $I_{p}$ & $\widetilde{\mathrm{L}}$ & Country & $\mathrm{I}_{\mathrm{p}}$ & $\widetilde{\mathrm{L}}$ \\
\hline United Arab Emirates & 0,6883 & 0,6436 & Jordan & 0,3190 & 0,2993 \\
\hline Argentina & 0,3310 & 0,2146 & Japan & 0,7432 & 0,5323 \\
\hline Australia & 0,7661 & 0,5968 & Kazakhstan & 0,3715 & 0,3485 \\
\hline Austria & 0,7364 & 0,6908 & Kenya & 0,2519 & 0,2363 \\
\hline Azerbaijan & 0,3772 & 0,3539 & Cambodia & 0,1171 & 0,1099 \\
\hline Belgium & 0,7131 & 0,1635 & South Korea & 0,7673 & 0,7171 \\
\hline Bangladesh & 0,1601 & 0,1502 & Laos & 0,1278 & 0,1199 \\
\hline Bulgaria & 0,4600 & 0,4316 & Lebanon & 0,2316 & 0,2173 \\
\hline Bahrain & 0,5892 & 0,5527 & Sri Lanka & 0,2670 & 0,2505 \\
\hline Bosnia \& Herzegovina & 0,2546 & 0,2388 & Lithuania & 0,6511 & 0,6108 \\
\hline Bolivia & 0,1057 & 0,0992 & Latvia & 0,5922 & 0,5556 \\
\hline Brazil & 0,2893 & 0,1031 & Morocco & 0,2129 & 0,1997 \\
\hline Canada & 0,7783 & 0,7294 & Mexico & 0,3100 & 0,1200 \\
\hline Switzerland & 0,8124 & 0,7619 & Malaysia & 0,6317 & 0,5926 \\
\hline Chile & 0,5573 & 0,5228 & Namibia & 0,2361 & 0,2215 \\
\hline China & 0,3935 & 0,3265 & Nigeria & 0,1129 & 0,1059 \\
\hline Côte d'lvoire & 0,0971 & 0,0911 & Netherlands & 0,7917 & 0,6491 \\
\hline Cameroon & 0,0955 & 0,0896 & Norway & 0,8096 & 0,7596 \\
\hline Colombia & 0,2764 & 0,2361 & New Zealand & 0,7707 & 0,7230 \\
\hline Costa Rica & 0,3909 & 0,3668 & Pakistan & 0,1687 & 0,1583 \\
\hline Czechia & 0,6291 & 0,5902 & Peru & 0,1937 & 0,1817 \\
\hline Germany & 0,7641 & 0,6928 & Philippines & 0,2421 & 0,2271 \\
\hline Denmark & 0,7986 & 0,7492 & Poland & 0,5781 & 0,5423 \\
\hline Algeria & 0,1974 & 0,1852 & Portugal & 0,6290 & 0,5901 \\
\hline Ecuador & 0,2404 & 0,2255 & Qatar & 0,5670 & 0,5319 \\
\hline Egypt & 0,2298 & 0,2156 & Romania & 0,4046 & 0,3796 \\
\hline Spain & 0,6342 & 0,5069 & Russia & 0,3885 & 0,0702 \\
\hline Estonia & 0,7229 & 0,6782 & Rwanda & 0,2114 & 0,1983 \\
\hline Ethiopia & 0,0743 & 0,0697 & Saudi Arabia & 0,5675 & 0,5324 \\
\hline Finland & 0,8328 & 0,7813 & Singapore & 0,8747 & 0,7382 \\
\hline France & 0,6982 & 0,4651 & Serbia & 0,3991 & 0,3744 \\
\hline United Kingdom & 0,7939 & 0,1578 & Slovakia & 0,5518 & 0,5176 \\
\hline Georgia & 0,3972 & 0,3726 & Slovenia & 0,6192 & 0,5809 \\
\hline Ghana & 0,1917 & 0,1799 & Sweden & 0,7858 & 0,5880 \\
\hline Greece & 0,4701 & 0,3605 & Thailand & 0,4153 & 0,3864 \\
\hline Hong Kong & 0,7996 & 0,7501 & Tunisia & 0,2237 & 0,2099 \\
\hline Croatia & 0,4817 & 0,4519 & Turkey & 0,4192 & 0,3924 \\
\hline Hungary & 0,4903 & 0,4600 & Taiwan & 0,7557 & 0,7090 \\
\hline Indonesia & 0,3270 & 0,3067 & Tanzania & 0,1547 & 0,1451 \\
\hline India & 0,2870 & 0,2115 & Uganda & 0,1503 & 0,1410 \\
\hline Ireland & 0,7245 & 0,6797 & Ukraine & 0,3183 & 0,2884 \\
\hline Iran & 0,2785 & 0,2612 & Uruguay & 0,3996 & 0,3748 \\
\hline Iceland & 0,7925 & 0,7435 & United States & 0,8366 & 0,1516 \\
\hline Israel & 0,6702 & 0,6287 & Vietnam & 0,2960 & 0,2777 \\
\hline Italy & 0,5426 & 0,4974 & South Africa & 0,3313 & 0,3108 \\
\hline
\end{tabular}

Sources: developed by the authors.

Thus, the risk analysis of using fraudulent schemes to launder illegal income through neobanking services by economic agents and individuals showed that the highest risk is in those countries where the integrated rating based on the model of gravity analysis is more than $70 \%$. Eleven leaders are the following countries: Canada, Switzerland, Finland, Hong Kong, China, Iceland, South Korea, Norway, New Zealand, Singapore, Taiwan, Denmark.

It could be logically interpreted as a higher degree of innovative financial technologies development and public awareness of their use, and the financial and economic ability of these countries to use a modern and flexible neobank interface (Giebe et al., 2019). There are 23 countries with an average degree 
V., Koibichuk, N., Ostrovska, F., Kashiyeva, A., Kwilinski. Innovation Technology and Cyber Frauds Risks of Neobanks: Gravity Model Analysis

of risk: United Arab Emirates, Australia, Austria, Bahrain, Chile, Czechia, Germany, Spain, Estonia, Ireland, Israel, Japan, Lithuania, Latvia, Malaysia, Netherlands, Poland, Portugal, Qatar, Saudi Arabia, Slovakia, Slovenia, Sweden. For countries where the value of the integrated rating $\left(L_{j}\right)$ falls in the range of $25 \%$ to $50 \%$, there is a lower risk of money laundering through the services of neobanks. Such countries are $37 \%$ of the studied countries. Ukraine is in this range, i.e., the risk of using fraudulent schemes in using neobanking services is low (below average) (Mursalov et al., 2020, Bagmet and Haponova, 2018). On the one hand, it is a positive characteristic, and on the other - due to the low quality of development of the neobanking sector, the ability to use relevant services by economic agents, lack of developed infrastructure, and low level of knowledge of financial and economic aspects and digital innovation components (Buriak and Artemenko, 2018; Caporale et al., 2019; Vasylieva et al., 2018a; Aleksander et al., 2020; Dalevska et al., 2019; Kharazishvili et al., 2020). The fourth and last category is formed by countries where the integrated rating value is less than $25 \%$. These countries have a low risk of money laundering involving neobank services. These are Tunisia, Morocco, Rwanda, Algeria, Peru, Ghana, Belgium, Pakistan, United Kingdom, United States, Bangladesh, Tanzania, Uganda, Mexico, Laos, Cambodia, Nigeria, Brazil, Bolivia, Ivory Coast, Cameroon, Russia, Ethiopia. Interpretation of the results of this countries category is formally logical in terms of the development of their economies, the development of digital banking, potential (financial and social) opportunities to use such services (Dove et al., 2020; Rubanov et al., 2019), and the degree security organizations (Yarovenko et al., 2020) from the intervention of third-party attackers to misappropriate funds.

Conclusions. The study results allowed concluding the division of countries into groups according to the degree of risk of using the funds of both individuals and economic agents by fraudsters using neobanking opportunities to launder criminal proceeds. The sphere of existence of neobank services is relatively young. It has been actively developing since 2017 , but it is already evident that there are several problems related to the degree of protection of financial and economic information used in digital ecosystems. The problems above are caused by a new range of developing cyber-fraudulent money laundering schemes (both at the state level and in neobanks operating under appropriate licensing conditions) and the level of public awareness of the peculiarities of the use of neobank technologies.

The relevant services of state financial monitoring, law enforcement agencies, and economic agents within each country could use the study results to detail all aspects of money laundering risk considering a specific gradation.

Author Contributions: conceptualization, A. K.; methodology, V. K.; software, V. K. and N. O.; validation, V. K. and N. O.; formal analysis, A. K.; investigation V. K. and A. K.; resources, F. K.; data curation, F. K.; writing-original draft preparation, V. K.; writing-review and editing, A. K.; visualization, N. O.; supervision A. K. All authors have read and approved the final manuscript.

Funding. This work is carried out within the taxpayer-funded researches: Optimization and automation of financial monitoring processes to increase information security of Ukraine (Application ID: 0120U104810).

\section{References}

Access Private Market Data CB Insights: Neobank. Retrieved from [Link]

Akimova, L., Akimov, O., Mihus, I., Koval, Y., \& Dmitrenko, V. (2020). Improvement of the methodological approach to assessing the impact of public governance on ensuring the economic security of the state. Financial and credit activity: problems of theory and practice, 4(35), 180-190. [Google Scholar]

Akimova, L. M., Akimov, O. O., \& Liakhovich, O. O. (2017). State regulation of foreign economic activity. Scientific bulletin of Polissia, 1(4 (12)), 98-103.. [Google Scholar]

Aleksander, A., Krawczyk, D., Kuzior, A., \& Kwilinski, A. (2020). 'The Conditions Affecting the Functioning of the Mass Media and Social Media Based on Empirical Research Conducted in Ukraine.' In Khalid S. Soliman (Ed.), Proceedings of the 36th 
V., Koibichuk, N., Ostrovska, F., Kashiyeva, A., Kwilinski. Innovation Technology and Cyber Frauds Risks of Neobanks: Gravity Model Analysis

International Business Information Management Association (IBIMA) 4-5 November 2020 (pp. 10330-10342). Granada, Spain: IBIMA Publishing. Retrieved from [Link]

Bagmet, K. V., \& Haponova, O. (2018). Assessing the Impact on Social Sector: a Macroeconomic Approach. SocioEconomic Challenges, (2, Iss. 3), 103-108. [Googlle Scholar] [CrossRef]

Bilan, Y., Brychko, M., Buriak, A., \& Vasilyeva, T. (2019a). Financial, business and trust cycles: The issues of synchronization. Zbornik Radova Ekonomskog Fakultet au Rijeci, 37(1), 113-138. [Google Scholar] [CrossRef]

Bilan, Y., Rubanov, P., Vasylieva, T., \& Lyeonov, S. (2019b). The influence of industry 4.0 on financial services: Determinants of alternative finance development. Polish Journal of Management Studies, 19(1), 70-93. [Google Scholar] [CrossRef] Bogachov, S., Kwilinski, A., Miethlich, B., Bartosova, V., \& Gurnak, A. (2020). Artificial intelligence components and fuzzy regulators in entrepreneurship development. Entrepreneurship and Sustainability Issues, 8(2), 487. [Google Scholar] [CrossRef] Buriak, A., \& Artemenko, A. (2018). Reputation risk in banking: application for Ukraine. Financial Markets, Institutions and Risks,

2(2). 100-110. [Google Scholar] [CrossRef]

Buriak, A., Lyeonov, S., \& Vasylieva, T. (2015). Systemically important domestic banks: An indicator-based measurement approach for the Ukrainian banking system. Prague Economic Papers, 24(6), 715-728. [Google Scholar] [CrossRef

Caporale, G. M., Plastun, A., \& Oliinyk, V. (2019). Bitcoin fluctuations and the frequency of price overreactions. Financial Markets and Portfolio Management, 33(2), 109-131. [Google Scholar] [CrossRef]

Chakravorti, B., Bhalla, A. \& Chaturvedi, R. (2020). Which Economies Showed the Most Digital Progress in 2020. Retrieved from [Link]

Dalevska, N., Khobta, V., Kwilinski, A., \& Kravchenko, S. (2019). A model for estimating social and economic indicators of sustainable development. Entrepreneurship and Sustainability Issues, 6(4), 1839. [Google Scholar] [CrossRef]

Digital Evolution Index (DEI). Retrieved from [Link]

Dove, M., Balasubramanian, A., \& Narayanan, B.G. (2020). Transparency as a way of attaining quality, safety and optimal food purchases. SocioEconomic Challenges, 4(4). 48-62. [Google Scholar] [CrossRef]

Dzwigol, H. (2020). Innovation in Marketing Research: Quantitative and Qualitative Analysis. Marketing and Management of Innovations, 1, 128-135. [Google Scholar] [CrossRef]

Dzwigol, H., \& Dźwigoł-Barosz, M. (2018). Scientific Research Methodology in Management Sciences. Financial and Credit Activity: Problems of Theory and Practice, 2(25), 424-437. [Google Scholar] [CrossRef]

Dzwigol, H., Dzwigol-Barosz, M., Miśkiewicz, R., \& Kwilinski, A. (2020). Manager competency assessment model in the conditions of industry 4.0. Entrepreneurship and Sustainability Issues, 7(4), 2630. [Google Scholar] [CrossRef

Electronic Money Institution (EMI). Retrieved from [Link]

Ferwerda, J., Kattenberg, M., Chang, H. H., Unger, B., Groot, L., \& Bikker, J. (2011). Gravity Models of Trade-Based Money Laundering. DNB Working Paper, 318. [Google Scholar] [CrossRef]

Giebe, C., Hammerström, L., \& Zwerenz, D. (2019). Big data \& analytics as a sustainable customer loyalty instrument in banking and finance. Financial Markets, Institutions and Risks, 3(4). 74-88. [Google Scholar] [CrossRef

Juarez-Garcia, M. I. (2020). Personal Corruption \& Corrupting Laws: Montesquieu's Twofold Theory of Corruption. Business Ethics and Leadership, 4(4), 76-83. [Google Scholar] [CrossRef]

Karpa, M. I., Akimova, L. M., Akimov, O. O., Serohina, N., Oleshko, O., \& Lipovska, N. (2021). Public administration as a systemic phenomenon in society. AD ALTA: Journal of interdisciplinary research, (11), 56-62. [Google Scholar]

Kharazishvili, Y., Kwilinski, A., Grishnova, O., \& Dzwigol, H. (2020). Social Safety of Society for Developing Countries to Meet Sustainable Development Standards: Indicators, Level, Strategic Benchmarks (with Calculations Based on the Case Study of Ukraine). Sustainability, 12(21), 8953. [Google Scholar] [CrossRef]

Kuzior, A., Kwilinski, A., \& Tkachenko, V. (2019). Sustainable development of organizations based on the combinatorial model of artificial intelligence. Entrepreneurship and Sustainability Issues, 7(2), 1353. [Google Scholar] [CrossRef]

Kwilinski, A., \& Kuzior, A. (2020). Cognitive Technologies in the Management and Formation of Directions of the Priority Development of Industrial Enterprises. Management Systems in Production Engineering, 28(2), 133-138. [Google Scholar] [CrossRef]

Kwilinski, A., Vyshnevskyi, O., \& Dzwigol, H. (2020). Digitalization of the EU Economies and People at Risk of Poverty or Social Exclusion. Journal of Risk and Financial Management, 13(7), 142. [Google Scholar] [CrossRef]

Kyrylov, Y., Hranovska, V., Boiko, V., Kwilinski, A., \& Boiko, L. (2020). International Tourism Development in the Context of Increasing Globalization Risks: On the Example of Ukraine's Integration into the Global Tourism Industry. Journal of Risk and Financial Management, 13(12), 303. [CrossRef]

Levchenko, V., Boyko, A., Bozhenko, V., Savchenko, T., Humenna, Y., \& Pilin R. (2019). State regulation of the economic security by applying the neoteric approach to its assessment. Marketing and Management of Innovations, 4, 364-372. [Google Scholar] [CrossRef]

Levchenko, V., Kobzieva, T., Boiko, A. \& Shlapko, T. (2018). Innovations in assessing the efficiency of the instruments for the national economy de-shadowing: the state management aspect. Marketing and Management of Innovations, 4. 361-371. [Google Scholar] [CrossRef]

Lopez, B., García, D., \& Alcaide, A. (2019). Blockchain Technology Facing Socioeconomic Challenges. Promise versus Probability. SocioEconomic Challenges, 3(4). 13-24. [Google Scholar] [CrossRef] 
Lyeonov, S., Żurakowska-Sawa, J., Kuzmenko, O., \& Koibichuk, V. (2020). Gravitational and Intellectual Data Analysis to Assess the Money Laundering risk of Financial Institutions. Journal of International Studies, 13(4), 259-272. [Google Scholar] [CrossRef

Lyulyov, O., Pimonenko, T., Kwilinski, A., Dzwigol, H., Dzwigol-Barosz, M., Pavlyk, V., \& Barosz, P. (2021). The Impact of the Government Policy on the Energy Efficient Gap: The Evidence from Ukraine. Energies, 14(2), 373. [Google Scholar] [CrossRef]

Lyulyov, O., Us, Y., Pimonenko, T., Kwilinski, A., Vasylieva, T., Dalevska, N., Polcyn, J., \& Boiko, V. (2020). The Link between Economic Growth and Tourism: Covid-19 Impact. In Khalid S. Soliman (Ed.), Proceedings of the 36th International Business Information Management Association (IBIMA) 4-5 November 2020 (pp. 8070-8086). Granada, Spain: IBIMA Publishing. [Google Scholar]

Maksimova, T., Zhdanova, O., \& Bondarenko, T. (2020). Risk typology for peer-to-peer lending in a financial architecture transformed by digitalization and the epidemiological situation. International Journal of Pharmaceutical Research, 12(4). 3674-3678. [CrossRef]

Melnychenko, O. (2019). Application of artificial intelligence in control systems of economic activity. Virtual Economics, 2(3), 30-40. [Google Scholar] [CrossRef]

Melnychenko, O. (2020). Is Artificial Intelligence Ready to Assess an Enterprise's Financial Security? Journal of Risk and Financial Management, 13(9), 191. [Google Scholar] [CrossRef]

Melnychenko, O. (2021). The Energy of Finance in Refining of Medical Surge Capacity. Energies, 14(1), 210. [Google Scholar] [CrossRef

Milon, K., Nur-Al-Ahad, M., \& Monjurul Alam, A. B. M. (2018). The Deployment of Next Generation Access Network in the EU: Facts and Analysis of Regulatory Issues. Business Ethics and Leadership, 2(4). 6-17. [Google Scholar] [CrossRef

Miśkiewicz, R. (2019). Challenges facing management practice in the light of Industry 4.0: The example of Poland. Virtual Economics, 2(2), 37-47. [Google Scholar] [CrossRef]

Miśkiewicz, R. (2020a). Efficiency of Electricity Production Technology from Post-Process Gas Heat: Ecological, Economic and Social Benefits. Energies, 13(22), 6106. [Google Scholar] [CrossRef]

Miskiewicz, R. (2020b). Internet of Things in Marketing: Bibliometric Analysis. Marketing and Management of Innovations, 3 , 371-381. [Google Scholar] [CrossRef]

Miśkiewicz, R. (2021). The Impact of Innovation and Information Technology on Greenhouse Gas Emissions: A Case of the Visegrád Countries. Journal of Risk and Financial Management, 14(2), 59. [Google Scholar] [CrossRef]

Mursalov, M., Zeynalov, Z., Huseynova, A., Lyeonov, S., Kuzmenko, O., \& Bozhenko, V. (2020). Forecasting the risk of money laundering through financial intermediaries in Ukraine. Financial and credit activity: problems of theory and practice, 4.(35). 191-201. [Google Scholar] [CrossRef]

Naser, N. (2019). The Interaction between Profitability and Macroeconomic Factors for Future Examinations of European Banks Soundness - Theoretical Study. Financial Markets, Institutions and Risks, 3(3), 63-97. [Googlle Scholar] [CrossRef] Neobanks: a study on key traffic channels. Research from Accenture 2019. (2020). Retrieved from [Link]

Nur-Al-Ahad, M., \& Nusrat, S. (2019). New Trends in Behavioral Economics: A Content Analysis of Social Communications of Youth. Business Ethics and Leadership, 3(3). 107-115. [Google Scholar] [CrossRef]

Pajak, K., Kvilinskyi, O., Fasiecka, O., \& Miskiewicz, R. (2017). Energy security in regional policy in Wielkopolska region of Poland. Economics and Environment, 2(61), 122-138. [Google Scholar]

Rubanov, P., Vasylieva, T., Lyeonov, S., \& Pokhylko, S. (2019). Cluster analysis of development of alternative finance models depending on the regional affiliation of countries. Business and Economic Horizons, 15(1). 90-106. [Google Scholar] [CrossRef] Savchenko, T., Koibichuk, V., Boyko, A., \& Minchenko, M. (2020). Risk assessment of the banking groups usage in the shadow activities. Financial and credit activity: problems of theory and practice, 4(35). 37-43. [CrossRef]

Stagmeier, C., \& Friedental, G. (2020). Neobank 2021: in races to profitability. Strategy and Management. Retrieved from [Link] Ukrainian Financial Sector Transformation: digital financeю (2019). Rertrieved from [Link]

Strielkowski, W., \& Höschle, F. (2016). Evidence for economic convergence in the EU: The analysis of past EU enlargements. Technological and Economic Development of Economy, 22(4), 617-630. [Google Scholar] [CrossRef]

Us, H., Malyarets, L., Chudaieva, I., \& Martynova, O. (2018). Multi-Criteria Optimization of the Balanced Scorecard for the Enterprise's Activity Evaluation: Management Tool for Business-Innovations. Marketing and Management of Innovations, 3. 48-58. [Google Scholar] [CrossRef]

Vasilyeva, T., Lyeonov, S., Adamičková, I., \& Bagmet, K. (2018a). Institutional quality of social sector: The essence and measurements. Economics \& Sociology, 11(2), 248-262. [Google Scholar] [CrossRef]

Vasylieva, T. A., Leonov, S. V., Kryvych, Y. N., \& Buriak, A. V. (2017). Bank 3.0 concept: global trends and implications. Financial and credit activity: problems of theory and practice, 1(22), 4-10. [Google Scholar] [CrossRef]

Vasylieva, T., Lyeonov, S., Lyulyov, O., \& Kyrychenko, K. (2018b). Macroeconomic stability and its impact on the economic growth of the country. Montenegrin journal of economics, 14(1), 159-170. [Google Scholar] [CrossRef

Yarovenko, H., Kuzmenko, O., \& Stumpo, M. (2020). Strategy for Determining Country Ranking by Level of Cybersecurity. Financial Markets, Institutions and Risks, 4(3). 124-137. [Google Scholar] [CrossRef]

Zolkover, A., \& Terziev, V. (2020). The Shadow Economy: A Bibliometric Analysis. SocioEconomic Challenges, 4(3). 107-118. [Google Scholar] [CrossRef] 
V., Koibichuk, N., Ostrovska, F., Kashiyeva, A., Kwilinski. Innovation Technology and Cyber Frauds Risks of Neobanks: Gravity Model Analysis

Zwerenz, D. (2020). Performance incentives to increase motivation; potentials of meaningful activities in project management. SocioEconomic Challenges, 4(3). 95-118. [CrossRef]

Zahorskyi, V. S., Lipentsev, A. V., Yurystovska, N. Y., Mazii, N. H., \& Akimov, O. O. (2019). Financial and administrative aspects of small business development in Ukraine. Financial and credit activity: problems of theory and practice, 3(30), 351-360. [Google Scholar]

Віталія Койбічук, к.е.н., доцент, Сумський державний університет, Україна

Наталія Островська, д.е.н., доцент, Чернівецький національний університет імені Юрія Федьковича, Україна

Флора Кашиєва, Ph.D., доцент, Азербайджанський державний економічний університет, Азербайджан

Олексій Квілінський, Dr.Sc., професор, Лондонська академія науки і бізнесу, Великобританія; Сумський державний університет, Україна

Інноваційні технології та ризики кібершахрайства необанків: гравітаційне моделювання

У статті представлено результати дослідження факторів, які описують ефективність та потенціал інноваційних технологій сфери необанкінгу на прикладі 90 країн світу. Метою дослідження $€$ визначення рівня ризику використання інноваційних технологій сфери необанкінгу для відмивання кримінальних доходів. У роботі проаналізовано доцільність використання чотирьох факторів, які складаються 313 індикаторів цифрової еволюції. Першим фактором $€$ «умови постачання», який складається із трьох індикаторів, а саме: інфраструктура доступу, інфраструктура транзакцій та інфраструктура реалізації. Зазначені індикатори дозволяють оцінити в балах рівень розвитку цифрової та фрізично інфраструктури для забезпечення якісного функціонування цифрової економіки. Другий фактор «умови попиту» складається з чотирьох індикаторів: рівень якості людського потенціалу, рівень поглинання пристроїв, рівень широкосмугового цифрового зв'язку, поглинання цифрових платежів. Ці індикатори свідчать про бажання та здатність споживачів долучитись до цифрової економіки, а також їх володіння інструментами та навичками, необхідними для підключення до цифрової системи. Третій фактор «інституційне середовище» сформований із трьох індикаторів: інституційна ефективність та довіра, установи та бізнес-середовище, установи та цифрова екосистема. Ці показники дозволяють проаналізувати підтримку країнами норм законодавства в розрізі цифрових технологій, а саме: інвестування в цифровізацію економіки; регулювання якості та доступу до цифрових даних за допомогою нормативних актів. Четвертий фактор «інновації та зміни» складається з трьох індикаторів, які характеризують стан ключових інноваційних економічних системних входів (талантів та капіталу), процесів (співпраці між університетами та промисловістю) та результатів (нових масштабних цифрових продуктів та послуг). У ході дослідження авторами згруповано зазначені вище індикатори в узагальнювальний показник, який характеризує ступінь ризику використання послуг необанків економічними агентами чи фізичними особами з метою легалізації кримінальних доходів. Для досягнення поставленої мети, дослідження проведено у декілька етапів. На першому етапі обґрунтовано статистичну значущість та можливість використання досліджуваних показників; здійснено процедуру логарифмічної нормалізації. Авторами застосовано інструментарій описової статистики пакету Statgaphics Centurion для оцінки параметрів нормалізації. На другому етапі дослідження здійснено згортку індикаторів за допомогою середньої геометричної зваженої, яка характеризує середні темпи динаміки. На третьому етапі за допомогою методів гравітаційного моделювання було розраховано значення інтегральної рейтингової оцінки щодо ступеня ризику використання інноваційних технологій, послуг та сервісів необанкінгу для відмивання кримінальних коштів. За отриманими результатами встановлено, що 12,22\% досліджуваних країн мають високий ступінь ризику; 25,56\% - середній; для 25,56\% країн ризик є нижче середнього рівня для 36,66\% країн рівень ризику майже відсутній.

Ключові слова: необанки, інноваційні фрінансові технології, ризики кібершахрайства, компоненти цифрової еволюції, гравітаційне моделювання. 